\title{
Murine Arcuate Nucleus Kisspeptin Neurons Communicate with GnRH Neurons In Utero
}

\author{
Devesh Kumar, ${ }^{1,2}$ Maria Freese, ${ }^{2}$ Dagmar Drexler, ${ }^{2}$ Irm Hermans-Borgmeyer, ${ }^{2}$ Annette Marquardt, ${ }^{2}$ \\ and Ulrich Boehm ${ }^{1,2}$ \\ ${ }^{1}$ Department of Pharmacology and Toxicology, University of Saarland School of Medicine, D-66421 Homburg, Germany, and ${ }^{2}$ Center for Molecular \\ Neurobiology, D-20253 Hamburg, Germany
}

\begin{abstract}
Puberty is a transition period of reproductive development from juvenile stages to adulthood and depends upon the activity of gonadotropin-releasing hormone $(\mathrm{GnRH})$ neurons. $\mathrm{GnRH}$ neurons are initially activated in utero but remain quiescent throughout the juvenile period. Premature reactivation of GnRH neurons results in precocious puberty in mice and humans, but the mechanisms underlying developmental control of GnRH neuron activity remain unknown. The neuropeptide kisspeptin, a potent activator of GnRH neurons that is implicated as a critical permissive signal triggering puberty and a major regulator of the adult female hypothalamuspituitary-gonadal axis, is paradoxically produced by neurons in the developing brain well before puberty onset. Thus, the neural circuits controlling the timing of reproductive maturation remain elusive. Here, we delineate the underlying neural circuitry using conditional genetic transsynaptic tracing in female mouse embryos. We find that kisspeptin-producing neurons in the arcuate nucleus (ARC) already communicate with a specific subset of GnRH neurons in utero. We show that ARC kisspeptin neurons are upstream of GnRH neurons, and that GnRH neuron connectivity to ARC kisspeptin neurons does not depend on their spatial position in the brain. Furthermore, we demonstrate that the neural circuits between ARC kisspeptin and GnRH neurons are fully established and operative before birth. Finally, we find that most GnRH neurons express the kisspeptin receptor GPR54 upon circuit formation, suggesting that the signaling system implicated in gatekeeping puberty becomes operative in the embryo.
\end{abstract}

Key words: Cre recombinase; gene targeting; genetic transneuronal tracing; GPR54; kisspeptin; puberty

\section{Introduction}

Gonadotropin-releasing hormone $(\mathrm{GnRH})$ neurons originate from the olfactory placode and migrate into the brain during embryonic maturation (Schwanzel-Fukuda and Pfaff, 1989; Wray et al., 1989). After initial activation in the embryo (Aubert et al., 1985; Terasawa and Fernandez, 2001; Sisk and Foster, 2004; Wen et al., 2010), GnRH neurons are restrained and remain quiescent throughout the juvenile period until the onset of puberty (Bronson, 1981; Teles et al., 2008; Styne and Grumbach, 2008; Mayer et al., 2010; Abreu et al., 2013). Mice and humans harboring inactivating mutations in the genes encoding the neuropeptide kisspeptin (d'Anglemont de Tassigny et al., 2007; Topaloglu et al., 2012) or its G-protein-coupled receptor GPR54 (Seminara et al., 2003; de Roux et al., 2003) fail to initiate puberty and remain infertile. Therefore, kisspeptin/GPR54 signaling has been

\footnotetext{
Received Dec. 8, 2013; revised Jan. 17, 2014; accepted Feb. 4, 2014.

Author contributions: D.K. and U.B. designed research; D.K., M.F., D.D., I.H.-B., and A.M. performed research; D.K. and M.F. analyzed data; U.B. wrote the paper.

This research was supported by Deutsche Forschungsgemeinschaft Grant B01743/6 to U.B. We thank Olaf Pongs for continuous support. We also thank Linda Buck, Peter Mombaerts, Takeshi Sakurei, and Ari Waisman for providing plasmids; and Ali Derin, Ulrike Wolters, and Oliver Glaser for animal caretaking.

The authors declare no competing financial interests.

Correspondence should be addressed to Ulrich Boehm, Department of Pharmacology and Toxicology, University of Saarland School of Medicine, Kirrberger Strasse, Building 61.4, 66421 Homburg, Germany. E-mail: ulrich.boehm@uks.eu.

DOI:10.1523/JNEUROSCI.5123-13.2014

Copyright $\odot 2014$ the authors $\quad 0270-6474 / 14 / 343756-11 \$ 15.00 / 0$
}

implicated as a gatekeeper of puberty (Seminara and Crowley, 2008; Clarkson et al., 2010). Consistent with this, kisspeptin receptor antagonists delay puberty in rodents (Pineda et al., 2010), while kisspeptin administration itself advances puberty onset (Matsui et al., 2004; Navarro et al., 2004). In addition, kisspeptin has been implicated as a major regulator of the adult female hypothalamus-pituitary-gonadal (hpg) axis (Castellano et al., 2006; Smith et al., 2006; Clarkson, 2013). GPR54 is expressed in most GnRH neurons in adults (Irwig et al., 2004). In fact, kisspeptin is the most potent activator of GnRH neurons known to date (Han et al., 2005). Consistent with an important role of kisspeptin neurons in the regulation of reproductive physiology, adult female mice stop cycling upon acute toxin-mediated kisspeptin neuron ablation (Mayer and Boehm, 2011).

Paradoxically however, both kisspeptin and GPR54 are expressed in the developing brain long before puberty onset (Han et al., 2005; Fiorini and Jasoni, 2010; Cao and Patisaul, 2011; Desroziers et al., 2012; Brock and Bakker, 2013; Knoll et al., 2013). Whether kisspeptin/GPR54 signaling plays a functional role in the developing brain before puberty is not known. There are mainly two anatomically segregated populations of neurons that express kisspeptin in the female hypothalamus, one in the anteroventral periventricular nucleus (AVPe; Oakley et al., 2009) and the other in the arcuate nucleus (ARC) of the hypothalamus (Clarkson et al., 2009b). Distinct roles have been proposed for ARC and AVPe kisspeptin neurons during female reproductive 
maturation (Mayer et al., 2010). Despite their pivotal role in the regulation of reproductive physiology, little is known about the development and connectivity of kisspeptin neurons. Furthermore, previous attempts to find connections between GnRH and kisspeptin neurons before puberty failed (Clarkson and Herbison, 2006; Clarkson et al., 2010), leaving the neural circuits underlying temporal control of $\mathrm{GnRH}$ neurons during reproductive development elusive. Due to their scattered distribution within the ARC and AVPe, kisspeptin neural circuitry has been difficult to analyze using classical tracer injection methods (Yeo and Herbison, 2011). Here we generated two novel mouse strains for Cre-dependent genetic transsynaptic tracing to study the formation and activity of kisspeptin/GnRH neural circuitry in the developing female mouse embryo.

\section{Materials and Methods}

Generation of ROSA26-BL-IRES- -lacZ and ROSA26-GFP-TTC mice. To generate the ROSA26-BL(barley lectin)-IRES (internal ribosomal entry site)- $\tau$ lacZ targeting vector, we inserted a cDNA coding for BL (Horowitz et al., 1999; provided by Linda Buck, Howard Hughes Medical Institute, Seattle, WA) followed by an IRES- lacZ cassette (Rodriguez et al., 1999; provided by Peter Mombaerts, Max Planck Institute of Biophysics, Frankfurt, Germany) into the pROSA26STOP ${ }^{\star}$ IiMOG plasmid (Buch et al., 2005; provided by Ari Waisman, University of Mainz, Mainz, Germany) via AscI and FseI sites. In a complementary approach, we inserted a cDNA coding for tetanus toxin fragment $\mathrm{C}$ fused to GFP (GFP-TTC; Maskos et al., 2002; provided by Takeshi Sakurai, Japan Science and Technology Corporation, Tokyo, Japan) into the pROSA26STOP* IiMOG targeting vector via AscI and FseI sites to generate the ROSA26GFP-TTC targeting vector. The final targeting vectors were composed as follows: 5' ROSA26 genomic sequence, adenoviral splice acceptor, loxP site, 2X SV40 polyadenylation signal, flippase recombinase target (FRT)flanked $p g k$ promoter-driven neomycin resistance cassette, another transcriptional STOP cassette, a second loxP site in the same orientation as the first, BL-IRES- $\tau$ lacZ or GFP-TTC, and 3' ROSA26 genomic sequence. Both targeting vectors were linearized using BbvCI and electroporated into R1 mouse embryonic stem (ES) cells, and resistant clones were analyzed by Southern blotting using EcoRI and an external $600 \mathrm{bp}$ probe. Correctly targeted ES cells were injected into C57BL/6J blastocysts to generate chimeras that were backcrossed to $\mathrm{C} 57 \mathrm{BL} / 6 \mathrm{~J}$ animals to give ROSA26-BL-IRES- lacZ (R26-BIZ) and R26-GFP-TTC (R26-GTT) mice. Genomic DNA obtained from tail biopsy specimens was prepared by proteinase $\mathrm{K}$ (Roche) digestion and subsequent purification with DNA Isolation Reagent for genomic DNA (AppliChem) for genotyping.

Mice. Animal care and experimental procedures were performed in accordance with the guidelines established by the animal welfare committee of the University of Hamburg and the University of Saarland. Mice were kept under standard light/dark cycle with food and water ad libitum. Kisspeptin-IRES-Cre (KissIC; Mayer et al., 2010), GPR54-IRESCre (GPIC; Mayer and Boehm, 2011), R26-CAGS- $\tau$ GFP (eR26- $\tau$ GFP; Wen et al., 2011), R26-BIZ, and R26-GTT mice were all kept in a mixed (129/SvJ and C57BL/6J) background. All animals analyzed in this study were females heterozygous for the respective Cre and $R 26$ alleles. Littermates carrying one Cre or one $R 26$ allele, respectively, were used as controls. KissIC and GPIC animals were genotyped using CRE-forward $5^{\prime}$-aaacgttgatgccggtgaacgtgc- $3^{\prime}$ and CRE-reverse $5^{\prime}$-taacattctcccaccgtc agtacg-3' primers. eR26- $\tau$ GFP mice were genotyped with YFP-forward $5^{\prime}$-cctgagtgccgttgggcgcg- $3^{\prime}$ and YFP-reverse $5^{\prime}$-'cgcgcccaacggcactcagg- $3^{\prime}$ primers.

Tissue preparation. Pregnant KissIC/eR26- $\tau$ GFP, GPIC/eR26- $\tau$ GFP, KissIC/R26-BIZ, KissIC/R26-GTT, and KissIC/R26-BIZ/R26-GTT mice were anesthetized and killed by decapitation. Embryos were removed, washed in ice-cold $1 \times$ PBS, soaked in $4 \%$ paraformaldehyde (PFA; fixative) on ice for $1.5-4.5 \mathrm{~h}$, and then transferred to $30 \%$ sucrose for $24 \mathrm{~h}$. The embryos were frozen in tissue-freezing medium optimal cutting temperature (OCT) compound (Leica) and cut into $14 \mu \mathrm{m}$ sagittal sections with a cryostat. For gender determination, embryo tail biopsy spec-
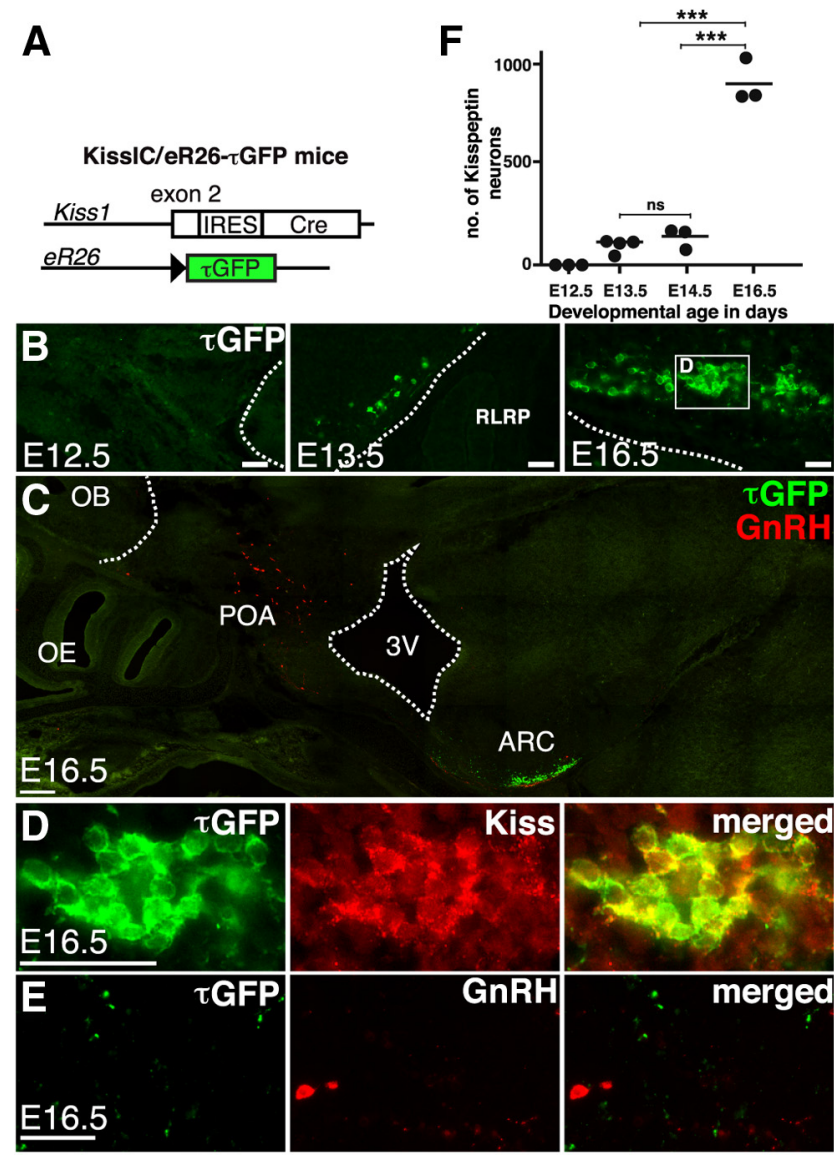

Figure 1. De novo expression and maturation of the kisspeptin system in female mice. $\boldsymbol{A}$ Genetic strategy to analyze the embryonic development of kisspeptin neurons. In KissIC/eR26$\tau$ GFP embryos, kisspeptin and $\tau$ GFP expression are genetically coupled, providing a fluorescent readout for Kiss 1 promoter activity. $\boldsymbol{B}$, Immunofluorescence for $\tau$ GFP (green) of a sagittal section through the head of female KissIC/eR26- $\tau$ GFP embryos at E12.5, E13.5, and E16.5. Kisspeptin neurons (green) are first found at E13.5 in the ARC. C, Double immunofluorescence for GnRH (red) and TGFP (green) of a sagittal section through the head of a female KissIC/eR26$\tau \mathrm{GFP}$ mouse at E16.5. Note that kisspeptin expression is restricted to the ARC, whereas GnRH neurons are scattered throughout the POA. D, Double immunofluorescence for kisspeptin (red) and $\tau$ GFP (green) demonstrates faithful activation of the $\tau$ GFP reporter in kisspeptin neurons. $\boldsymbol{E}, \tau \mathrm{GFP}^{+}$fibers project to the POA at E16.5. $\boldsymbol{F}$, Quantification of kisspeptin neurons during embryonic maturation. ${ }^{* * *} p<0.001$. RLRP, Residual lumen of Rathke's pouch; $\mathrm{OB}$, olfactory bulb; $0 \mathrm{E}$, olfactory epithelium; 3V, third ventricle. Scale bars: $\boldsymbol{B}, \boldsymbol{D}, \boldsymbol{E}, 50 \mu \mathrm{m} ; \boldsymbol{C}, 200 \mu \mathrm{m}$.

imens were digested in lysis buffer ( $50 \mathrm{~mm}$ Tris- $\mathrm{HCl}, \mathrm{pH} 8,100 \mathrm{~mm} \mathrm{NaCl}$, $0.2 \% \mathrm{NP} 40,0.2 \%$ Tween, $1 \mathrm{~mm}$ EDTA, $0.1 \mathrm{mg} \mathrm{ml}^{-1}$ proteinase $\left.\mathrm{K}\right)$ at $55^{\circ} \mathrm{C}$ and genotyped by PCR (Agulnik et al., 1997). At postnatal day 2 (P2; day of birth, P0), mice were transcardially perfused with fixative under ketamine/xylazine (Bayer) anesthesia, brains were removed, postfixed in $4 \%$ PFA for $2 \mathrm{~h}$ on ice, transferred to $30 \%$ sucrose for $24 \mathrm{~h}$, frozen in OCT compound, and cut into $14 \mu \mathrm{m}$ coronal sections with a cryostat (Boehm et al., 2005).

Immunofluorescence. The $14 \mu \mathrm{m}$ sagittal embryo head and coronal P2 brain sections from KissIC/eR26- $\tau$ GFP and GPIC/eR26- $\tau$ GFP mice were incubated in TNB blocking solution (PerkinElmer) for $1 \mathrm{~h}$ at $20-25^{\circ} \mathrm{C}$, followed by overnight incubation at $4^{\circ} \mathrm{C}$ with primary antisera in TNB blocking solution. The primary antisera used were (1) rabbit antibody to GnRH (1:1000; catalog \#PA1-121, Affinity BioReagents), (2) rabbit antibody to estrogen receptor $\alpha(\mathrm{ER} \alpha ; 1: 1000$; catalog \#06-935, Millipore), (3) rabbit antibody to kisspeptin (1:500; catalog \#AB9754, Millipore), and (4) Alexa Fluor 488 rabbit antibody to GFP (1:1000; catalog \#A21311, Invitrogen). In the case of using two primary antibodies from rabbit, sections were first stained with either rabbit antibody to $\mathrm{ER} \alpha$, to $\mathrm{GnRH}$, or to Kisspeptin, followed by monovalent Cy3-donkey antibody 
to rabbit IgG (1:500; catalog \#711-487-003, The Jackson Laboratory) for $2 \mathrm{~h}$ at $20-25^{\circ} \mathrm{C}$, and then blocked with $1 \%$ ChromPure rabbit IgG (catalog \#011-000-008, The Jackson Laboratory) for $2 \mathrm{~h}$ followed by Alexa Fluor 488 rabbit antibody to GFP (1:1000; Invitrogen) for $2 \mathrm{~h}$ at $20-25^{\circ} \mathrm{C}$. To visualize the transneuronal tracers BL and GFP-TTC, $14 \mu \mathrm{m}$ sagittal embryo head and coronal P2 brain sections from KissIC/R26-BIZ, KissIC/R26-GTT, and KissIC/R26GTT/R26BIZ mice were treated with goat anti-serum against wheat germ agglutinin [1:1000; catalog \#AS-2024, Vector Laboratories (which recognizes $\mathrm{BL}$ )] in TNB blocking solution at $4^{\circ} \mathrm{C}$ followed by biotinylated horse anti-goat IgG (catalog \#BA-9500, Vector Laboratories) at $1: 500$ for $1 \mathrm{~h}$ at $20-$ $25^{\circ} \mathrm{C}$ or with rabbit anti-GFP (catalog \#A11122, Invitrogen) at $1: 15,000$ in TNB blocking solution at $4^{\circ} \mathrm{C}$ overnight followed by biotinylated goat antiserum against rabbit IgG (1:5000; catalog \#BA-1000, Vector Labs) for $1 \mathrm{~h}$ at $20-25^{\circ} \mathrm{C}$, and then treated with components of the TSA kit (BL; PerkinElmer) or the TSA+ kit (GFP; PerkinElmer) according to the manufacturer's instruction. Sections were then incubated with Alexa Fluor 546-streptavidin (1: 500; catalog $\#$ S11225, Invitrogen) in TNB blocking solution for $30 \mathrm{~min}$ at $20-25^{\circ} \mathrm{C}$ followed by rabbit anti-GnRH $(1: 1000)$ at $4^{\circ} \mathrm{C}$ overnight and Dylight488-donkey antiserum against rabbit IgG (catalog \#SA5-10038, Thermo Scientific) for $2 \mathrm{~h}$ at $20-25^{\circ} \mathrm{C}$. For nuclear staining, sections were incubated with 5 $\mu \mathrm{g} \mathrm{ml}^{-1}$ Hoechst 33258 dye (Sigma) in $0.1 \mathrm{M}$ PBS for $10 \mathrm{~min}$ and mounted with Fluoromount-G (Southern Biotech). Appropriate controls omitting primary antibodies were performed and did not yield any staining. Sections were analyzed on an Axioskop2 microscope equipped with AxioVision software (Zeiss).

LacZ staining. Embryo sections were fixed with $0.2 \%$ glutaraldehyde (Boehringer Ingelheim), $2 \mathrm{~mm} \mathrm{MgCl}_{2}, 5 \mathrm{~mm}$ EGTA, $1 \times$ sodium phosphate buffer, $\mathrm{pH} 7.3$, for 2 min at $20-$ $25^{\circ} \mathrm{C}$, followed by a $30 \mathrm{~min}$ wash with wash buffer A ( $2 \mathrm{~mm} \mathrm{MgCl}_{2}, 5 \mathrm{~mm}$ EGTA in $1 \times$ sodium phosphate buffer, $\mathrm{pH}$ 7.3 ) and a 10 min wash with wash buffer B ( $2 \mathrm{~mm} \mathrm{MgCl}_{2}, 0.01 \%$ sodium deoxycholate, $0.02 \%$ Nonidet $\mathrm{P} 40,1 \times$ sodium phosphate buffer, $\mathrm{pH}$ 7.3). Sections were then incubated overnight in $1 \times$ sodium phosphate buffer, $\mathrm{pH} 7.3$, containing $0.5 \mathrm{mg} \mathrm{ml}^{-1} \mathrm{X}$-gal $\left(40 \mathrm{mg} \mathrm{ml}^{-1}\right.$ stock solution in dimethylformamide), $0.5 \mathrm{mg} \mathrm{ml}^{-1} \mathrm{NBT}\left(50 \mathrm{mg} \mathrm{ml}^{-1}\right.$ stock solution in $70 \%$ dimethylformamide), and $2 \mathrm{mM} \mathrm{MgCl}_{2}$ at $30^{\circ} \mathrm{C}$, followed by a wash with $1 \times$ sodium phosphate buffer, $\mathrm{pH} 7.3$, and then mounted with Mayer's glycine gelatin. Sections were analyzed on a Zeiss Axiophot light microscope equipped with a differential interference contrast imaging setup. Brain structures were identified using a prenatal mouse brain atlas (Schambra, 2008) and an atlas of mouse development (Kaufmann, 2001).

Quantification of neurons. Neurons were manually counted in every fifth section extending through the entire embryonic head (sagittal sections) and postnatal brain (coronal sections), respectively, using the ImageJ Cell Counter plugin. All sections were counterstained with Hoechst 33258 dye before analysis to visualize nuclei. Note that the $\tau$ GFP fusion protein is excluded from the nucleus due its size (Wen et al., 2011). Kisspeptin, GPR54, and GnRH neurons were counted based on positively stained cytoplasm, and $\mathrm{ER} \alpha$ neurons were counted based on nuclear signal. Counted numbers were multiplied by 2.5 to give estimates of the total number of neurons per brain (Boehm et al., 2005).
Statistical methods. All data are presented as the mean \pm SEM. Twotailed unpaired Student's $t$ tests were used to determine statistical significance in all experiments. In addition, one-way ANOVA with Tukey's multiple-comparison test was used to determine statistical significance when making comparisons between different age groups.

\section{Results}

\section{Orchestrated onset of kisspeptin and GPR54 expression in female mouse embryos}

We first investigated the de novo expression of kisspeptin in female KissIC/eR26- $\tau$ GFP embryos, which report Kiss1 promoter activity (Mayer et al., 2010). KissIC (Kisspeptin-IRESCre) mice carry a targeted insertion of an IRES followed by a Cre recombinase cDNA downstream of the kisspeptin coding sequence (Fig. 1A). Transcription of the recombinant Kiss 1 allele yields a bicistronic mRNA from which kisspeptin and Cre recombinase are independently translated. The eR26- $\tau \mathrm{GFP}$ (ROSA26-CAGS- $\tau$ GFP) reporter strain expresses a fusion of the microtubule-associated protein ( $\tau \mathrm{GFP}$ ) under control of the $\beta$-actin promoter/CMV enhancer (CAGS) in the ROSA26 locus after Cre-mediated excision of a transcriptional stop signal (Wen 
A
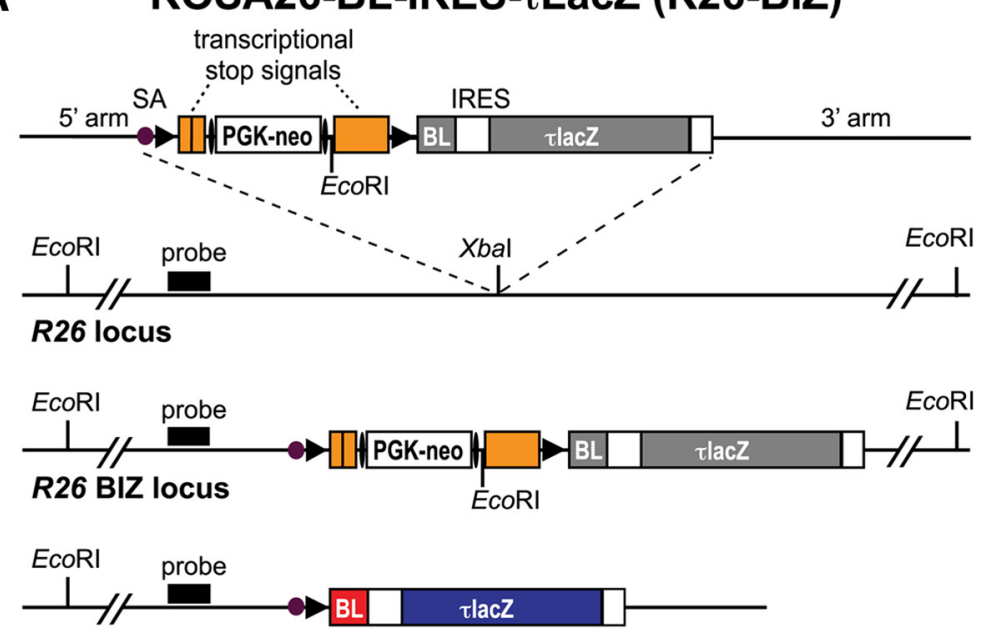

R26 BIZ locus after Cre-mediated recombination
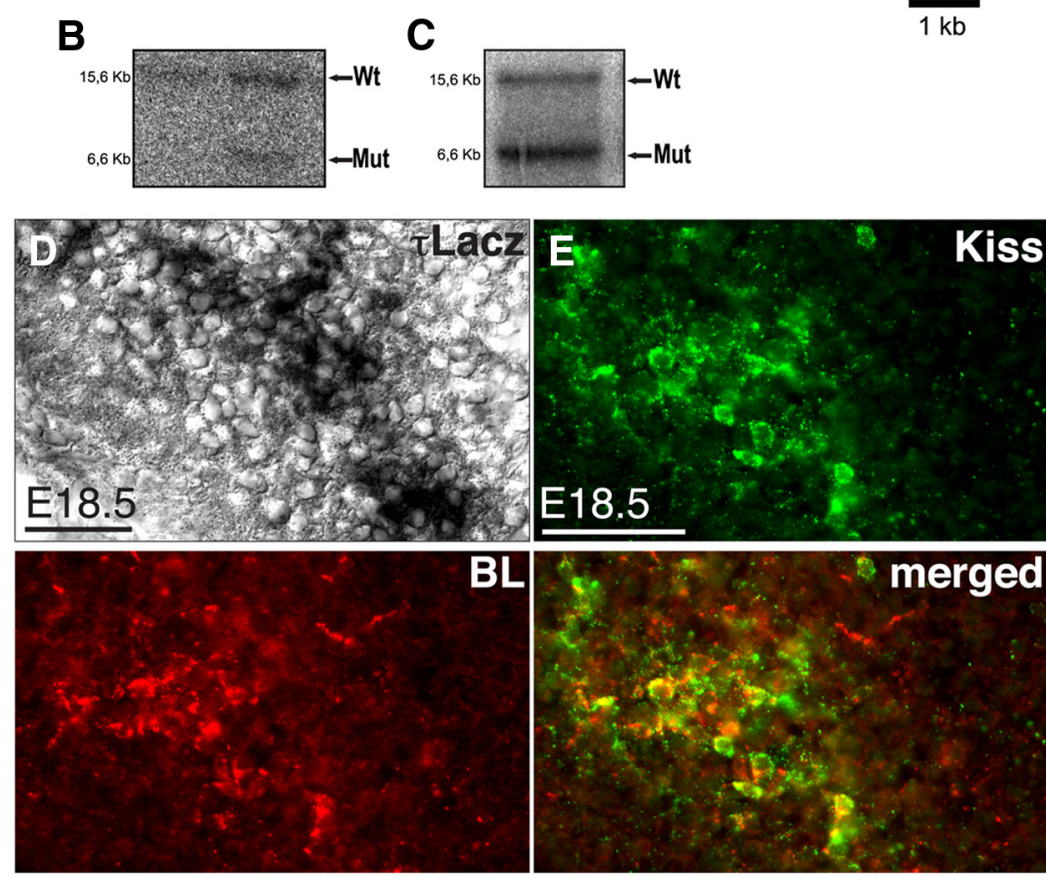

Figure 3. Targeted integration of a Cre-dependent BL-IRES- $\tau$ lacZ transneuronal tracer into the $R 26$ locus. $\boldsymbol{A}$, Schematic representation of the targeting strategy. From top to bottom: the targeting vector, the wild-type $R 26$ allele, and the targeted $R 26$ allele before and after Cre-mediated recombination are shown. The targeting vector contains a lox $P$-flanked transcriptional stop cassette with an FRT-flanked phosphoglycerate kinase promoter-driven neomycin resistance gene (PGK-neo), and the coding sequence for BL-IRES- TlacZ. LoxP and FRT sites are indicated by solid arrowheads and ellipses, respectively. SA, Adenovirus splice acceptor sequence. $\boldsymbol{B}$, Southern blot analysis of genomic ES cell DNA. The expected fragment sizes detected by the probe are indicated (wild-type, $15.6 \mathrm{~kb}$; mutant, $6.6 \mathrm{~kb}$ ). C, Germline transmission of the R26-BIZ allele was confirmed by Southern blot analysis of tail DNA. D, Histochemical analysis of $\beta$-galactosidase activity in a female KissIC/R26-BIZ brain at E18.5. The section is adjacent to the one shown in $\boldsymbol{E}$. $\boldsymbol{E}$, Antibodies against kisspeptin demonstrate faithful activation of BL in kisspeptin neurons. Scale bars: $\boldsymbol{D}, 20 \mu \mathrm{m}$; $\boldsymbol{E}, 50 \mu \mathrm{m}$. Wt, Wild type; Mut, mutant.

et al., 2011). Kisspeptin neurons in KissIC/eR26- 7 GFP doubleheterozygous mice express $\tau$ GFP from the recombined ROSA26 allele and are thus identifiable by fluorescence. While we did not detect any kisspeptin expression at embryonic day 12.5 (E12.5; $n=3$ mice; Fig. $1 B$ ), we observed $116 \pm 22$ kisspeptin neurons ( $n=4$ mice) at E13.5 in the ARC of the hypothalamus (Fig. $1 B, F)$. At E14.5, we found $145 \pm 34$ kisspeptin neurons $(n=3$ mice), which increased to $907 \pm 63$ ( $n=3$ mice) at E16.5 ( $p<$ 0.001 ) and remained restricted to the ARC (Fig. $1 B, C, F$ ). We immunostained for kisspeptin and found that $91 \pm 3 \%$ of the $\tau \mathrm{GFP}^{+}$cells (304 \pm 46 kisspeptin ${ }^{+} / \tau \mathrm{GFP}^{+}$ of $333 \pm 44 \pi \mathrm{GFP}^{+} ; n=3$ mice) express kisspeptin at E16.5, demonstrating faithful activation of the $\tau$ GFP reporter in kisspeptin neurons (Fig. 1D). At this stage, kisspeptin neurons send projections to the preoptic area (POA; Fig. $1 E)$.

Next, we questioned when GnRH neurons start to express the kisspeptin receptor GPR54, and thus may become responsive to kisspeptin. To analyze this, we used female GPIC/eR26- $\tau$ GFP mice (Mayer and Boehm, 2011), which report GPR54 promoter activity (Fig. $2 A$ ). While we did not detect any GPR54 expression at E12.5 (Fig. 2B,E), $\sim 3 \%$ of GnRH neurons expressed GPR54 at E13.5 ( $7 \pm 0.8$ $\tau \mathrm{GFP}^{+} / \mathrm{GnRH}^{+}$of $215 \pm 21 \mathrm{GnRH}^{+}$, $n=3$ mice; Fig. $2 C, F, H)$. At this embryonic age, we observed GnRH neurons in the nasal septum, at the junction between the nasal septum and the anterior forebrain, and in the anterior forebrain itself (Fig. 2C). The percentage of GnRH neurons expressing GPR54 increased to $\sim 8 \%$ at E14.5 $\left(21 \pm 0.5 \tau \mathrm{GFP}^{+} / \mathrm{GnRH}^{+}\right.$of $265 \pm 14 \mathrm{GnRH}^{+}, n=3$ mice; $p<0.01$, E13.5 vs E14.5). At E16.5, the majority of GnRH neurons were found in the anterior forebrain (mainly in the septum, in the organum vasculosum of the lamina terminalis, and in the preoptic area; Fig. 2D). At this age, $\sim 50 \%$ of the GnRH neuron population expressed GPR54 $(116 \pm 12$ $\tau \mathrm{GFP}^{+} / \mathrm{GnRH}^{+}$of $249 \pm 18 \mathrm{GnRH}^{+}$, $n=3$ mice; $p<0.001$, E14.5 vs E16.5) to reach $>81 \%$ at $\mathrm{P} 2\left(165 \pm 12 \tau \mathrm{GFP}^{+}\right.$/ $\mathrm{GnRH}^{+}$of $203 \pm 10 \mathrm{GnRH}^{+}, n=3$ mice; $p<0.01$, E16.5 vs P2). Throughout embryonic development, GPR54 expression was exclusively restricted to $\mathrm{GnRH}$ neurons (Fig. 2B-D). GPR54 expression in GnRH neurons did not depend on GnRH spatial position as $\mathrm{GnRH}^{+} / \mathrm{GPR}^{+} 4^{+}$and $\mathrm{GnRH}^{+} / \mathrm{GPR} 54-$ neurons were found in all areas containing GnRH neurons (Fig. 2). Together, these data demonstrate orchestrated onset of kisspeptin and GPR54 expression in the embryo at E13.5, raising the possibility that the signaling system implicated in gatekeeping puberty becomes operative in utero.

ARC kisspeptin neurons communicate with a subset of GnRH neurons in utero

Therefore, we next asked whether ARC kisspeptin neurons become connected to and communicate with GnRH neurons during embryonic maturation. Despite recent technical advances in conditional transneuronal tracing using genetically engineered neurotrophic viruses, however (Lo and Anderson, 2011), studying the formation of neural circuits during embryonic development remains especially challenging. 
To overcome this, we generated two new mouse strains allowing conditional transsynaptic tracing after Cre-mediated recombination. We first inserted a Credependent expression cassette consisting of the transneuronal tracer BL (Horowitz et al., 1999) followed by an IRES and a fusion of the microtubule-associated protein $\tau$ with lacZ (i.e., BL-IRES- $\tau$ lacZ) into the R26 locus (R26-BIZ) locus (Fig. 3A$E)$. After Cre-mediated excision of transcriptional stop signals, BL is transferred across synapses in both retrograde and anterograde directions, labeling neurons upstream and downstream of the Creproducing cells, whereas the axonal marker $\tau$ lac $Z$ is restricted to the producing cells (Fig. $4 A)$. We then prepared sections through the brain of female KissIC/R26-BIZ doubleknock-in embryos and immunostained these with antiserum against BL (Fig. 4). Whereas $\tau$ lac $Z$ was restricted to the ARC (Fig. $4 B$ ), we detected $\mathrm{BL}^{+}$vesicles in the POA of the hypothalamus first at E16.5 (Fig. 4D), suggesting transsynaptic transfer of the BL tracer. At E18.5, we immunostained for $\mathrm{GnRH}$ and found that the $\mathrm{BL}^{+}$vesicles in the POA were exclusively restricted to GnRH neurons (Fig. 4E). Not all GnRH neurons contained the BL tracer, suggesting functional specialization within the $\mathrm{GnRH}$ neuron population (Fig. $4 F$ ). A total of $59 \%$ of GnRH neurons $\left(145 \pm 13 \mathrm{BL}^{+} / \mathrm{GnRH}^{+}\right.$of $246 \pm 17$ $\mathrm{GnRH}^{+}$neurons; $n=3$ mice) contained the BL tracer at this stage (Fig. $4 G$ ), demonstrating that kisspeptin neurons are already synaptically connected to a subset of GnRH neurons in the embryo.

\section{ARC kisspeptin neurons are upstream of GnRH neurons}

To determine whether GnRH neurons are upstream or downstream of kisspeptin neurons, we then generated-in a complementary genetic approach - a second recombinant $R 26$ allele containing GFPTTC (Maskos et al., 2002; Fig. 5A-D, R26GTT). Upon activation, GFP-TTC is selectively transferred across synapses in a retrograde manner (Maskos et al., 2002), thus exclusively labeling neurons upstream of the Cre-producing cells (Fig. $6 A)$. We then prepared sections through the brain of female KissIC/R26-BIZ/R26-GTT triple-knock-in embryos, and immunostained these with antisera against BL and GFP-TTC. While BL was clearly detected in GnRH neurons as early as E16.5, we did not find the GFP-TTC tracer in these cells at any age analyzed (E16.5, E18.5, and P2; Fig. 6G-I), demonstrating that kisspeptin neurons are upstream of $\mathrm{GnRH}$ neurons. Transsynaptic transfer of the GFP-TTC tracer was, however, obvious in other areas of the brain at E18.5, an important control (Fig. 6J-M). GFP-TTCpositive cell bodies were found in the ventromedial, lateral (Fig.
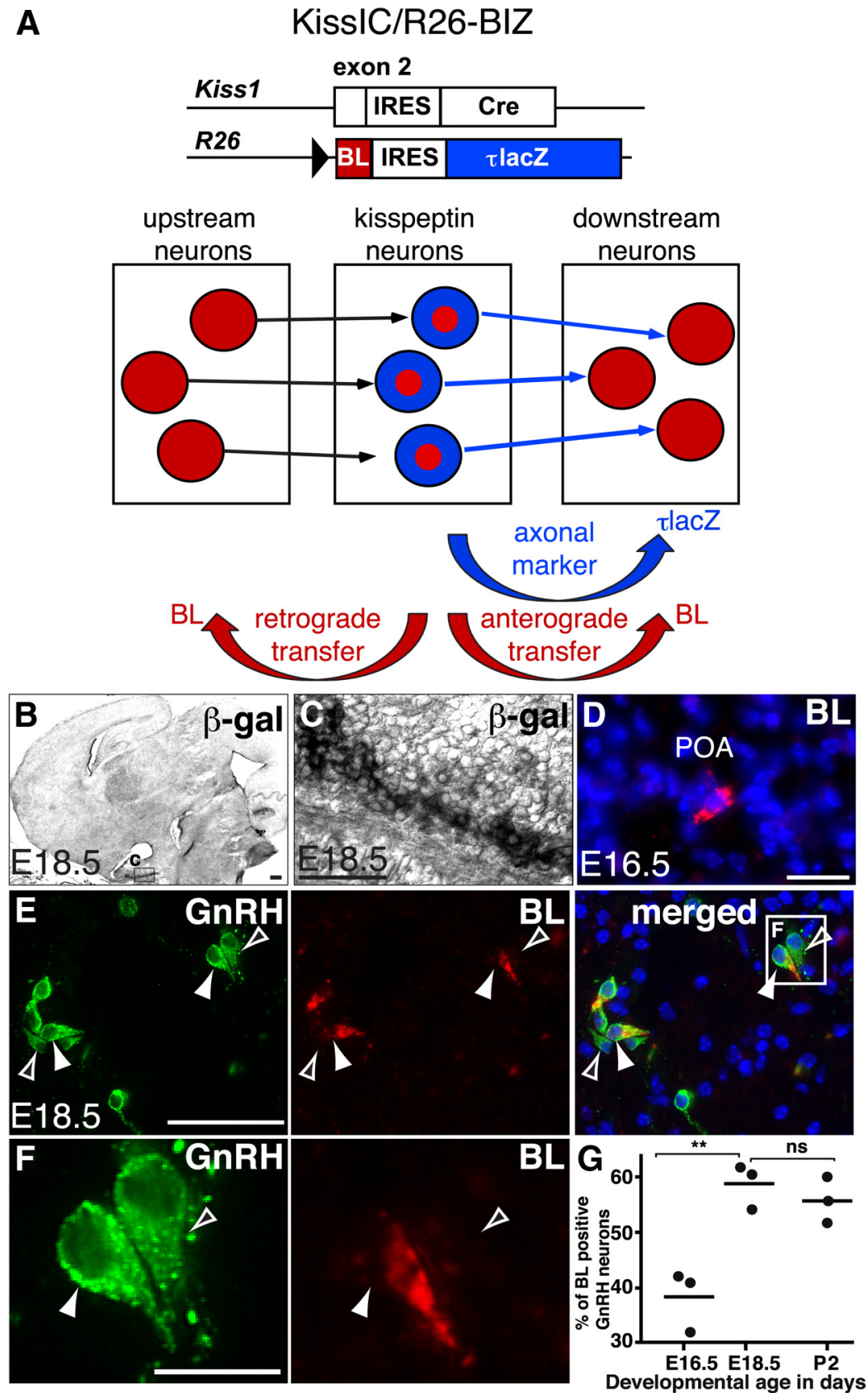

Figure 4. Arcuate nucleus kisspeptin neurons communicate with a subset of GnRH neurons in utero. A, In KissIC/R26-BIZ mice, tlacZ is confined to kisspeptin neurons, but $\mathrm{BL}$ is transferred to presynaptic and postsynaptic neurons. $\boldsymbol{B}, \boldsymbol{C}, \boldsymbol{\beta}$-galactosidase activity ( $\beta$-gal) is restricted to the ARC in a female KissIC/R26-BIZ brain at E18.5. D, BL-filled vesicles are found in the P0A at E16.5. $\boldsymbol{E}, \boldsymbol{F}$, Immunofluorescence for $\mathrm{GnRH}$ (green) and BL (red) demonstrates BL transfer to some (filled arrowhead) but not all (open arrowhead) GnRH neurons. G, Quantification of GnRH neurons communicating with kisspeptin neurons during reproductive maturation. Note that the number of $\mathrm{GnRH}$ neurons connected to kisspeptin neurons does not increase between $\mathrm{E} 18.5$ and $\mathrm{P} 2$, suggesting that connectivity to kisspeptin neurons is established before birth. ${ }^{* *} p<0.01$. Scale bars: $\boldsymbol{C}, \boldsymbol{F}, 20 \mu \mathrm{m} ; \boldsymbol{D}, \boldsymbol{E}, 50 \mu \mathrm{m} ; \boldsymbol{B}, 200 \mu \mathrm{m}$.

$6 \mathrm{~K})$, and posterior hypothalamus. Interestingly we did not detect any GFP-TTC-positive cells outside of the hypothalamus at this developmental stage (Fig. 6G,J). These data demonstrate that GFP-TTC is transsynaptically transferred to neurons upstream of kisspeptin neurons in KissIC/R26-BIZ/R26-GTT animals.

Connectivity to ARC kisspeptin neurons does not depend on GnRH neuron spatial position

We observed $\mathrm{GnRH}$ neurons with and without the BL tracer immediately adjacent to each other (Figs. $4 E, F$, Fig. $6 D-F$ ) in all 
A
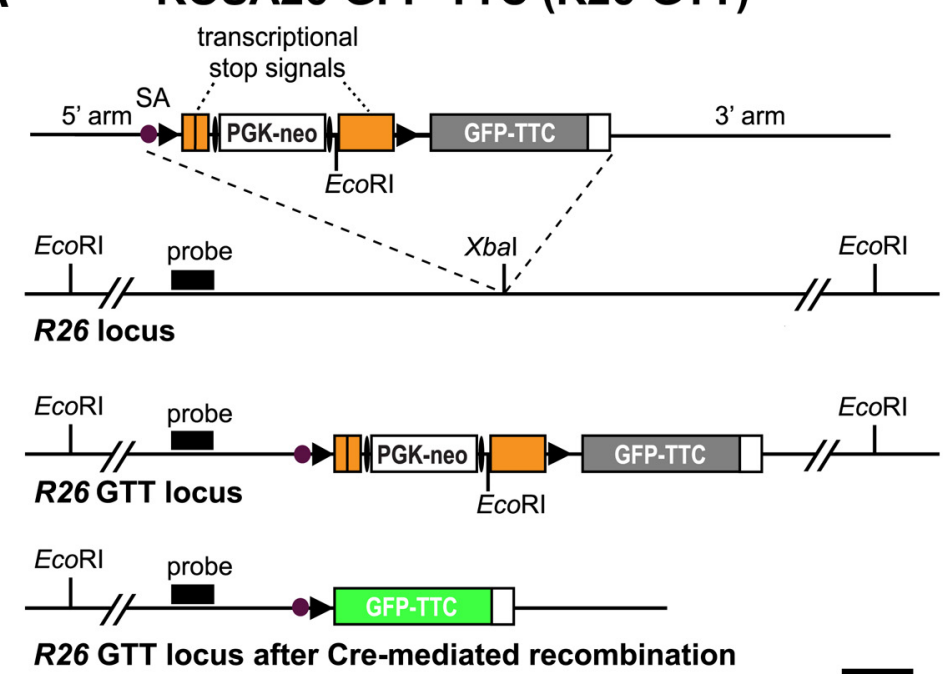

\section{R26 GTT locus after Cre-mediated recombination}

B

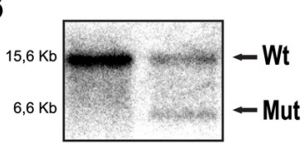

C
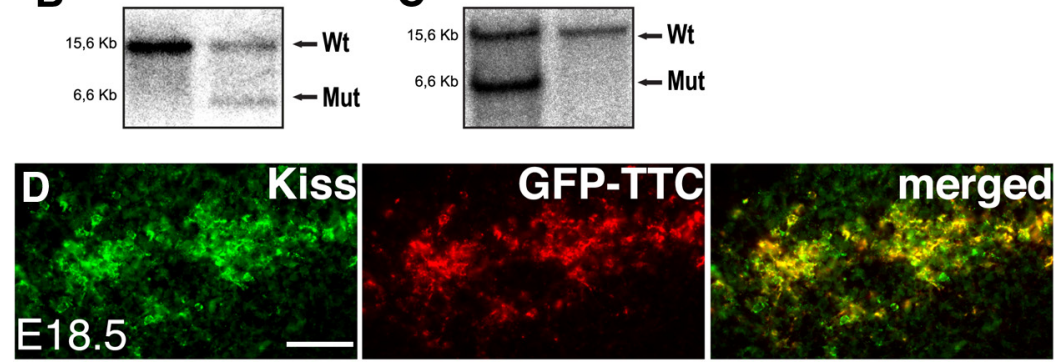

Figure 5. Targeted integration of a Cre-dependent GFP-TTC transneuronal tracer into the $R 26$ locus. $A$, Schematic representation of the targeting strategy. From top to bottom: the targeting vector, the wild-type $R 26$ allele, and the targeted $R 26$ allele before and after Cre-mediated recombination are shown. The targeting vector contains a loxP-flanked transcriptional stop cassette with a FRT-flanked phosphoglycerate kinase promoter-driven neomycin resistance gene (PGK-neo), and the coding sequence for GFPTTC. LoXP and FRT sites are indicated by solid arrowheads and ellipses, respectively. SA, Adenovirus splice acceptor sequence. $\boldsymbol{B}$, Southern blot analysis of genomic ES cell DNA. The expected fragment sizes detected by the probe are indicated (wild-type, $15.6 \mathrm{~kb}$; mutant, $6.6 \mathrm{~kb}$ ). C, Germline transmission of the R26-GTT allele was confirmed by Southern blot analysis of tail DNA. D, Antibodies against kisspeptin demonstrate faithful activation of GFP-TTC in kisspeptin neurons. Scale bar, $50 \mu \mathrm{m}$. Kiss, Kisspeptin; Wt, wild type; Mut, mutant.

hypothalamic nuclei containing GnRH neurons (Fig. 7), demonstrating that connectivity to kisspeptin neurons depends neither on their spatial position within an area nor on their spatial position in the brain. Together, our data reveal that the first formation of neural circuits between kisspeptin and GnRH neurons occurs in utero.

Neural circuits between ARC kisspeptin and GnRH neurons are fully established and operative before birth

Previous studies have indicated that transfer of BL across synapses depends on synaptic activity (Tabuchi et al., 2000; Nakashiba et al., 2012), raising the possibility that arcuate nucleus kisspeptin neurons communicate with GnRH neurons in utero. We therefore next analyzed communication between kisspeptin and GnRH neurons at different developmental time points using BL transfer as a marker for synaptic activity. Of note, the expression of the transneuronal tracer BL in kisspeptin neurons is independent of Kiss 1 promoter activity after Cre-mediated activation (Fig. $3 A$ ). The number of GnRH neurons communicating with kisspeptin neurons initially increased from $38 \%\left(111 \pm 8 \mathrm{BL}^{+} / \mathrm{GnRH}^{+}\right.$of $290 \pm 2 \mathrm{GnRH}^{+}$; $n=3$ mice) at E16.5 to $59 \%$ at E18.5, reaching a plateau, which then remained constant after birth $\left[118 \pm 9 \mathrm{BL}^{+} / \mathrm{GnRH}^{+}\right.$of $210 \pm 11.5$
$\mathrm{GnRH}^{+}(56 \%)$ at P2; $n=3$ mice; Fig. $\left.4 G\right]$. These data suggest that the neural circuits between ARC kisspeptin and GnRH neurons are fully established and operative before birth.

$\mathrm{ER} \alpha$ immunoreactivity within the embryonic female brain delineates the birthplace of kisspeptin neurons We have recently shown that GnRH neuron activity before puberty depends on $\mathrm{ER} \alpha$ signaling in kisspeptin neurons, as female mice lacking $\mathrm{ER} \alpha$ in these cells show premature activation of GnRH neurons resulting in precocious puberty onset (Mayer et al., 2010). We therefore asked when embryonic ARC kisspeptin neurons might become estrogen sensitive. Immunofluorescence analysis using antibodies against $\mathrm{ER} \alpha$ showed that $\mathrm{ER} \alpha$ immunoreactivity is essentially restricted to one area within the developing female mouse brain at E13.5 (Fig. 8A). Strikingly, we found that the $\operatorname{ER} \alpha$-positive area delineates the birthplace of kisspeptin neurons in the arcuate nucleus (Fig. 8B). Consistent with a functional role of $\mathrm{ER} \alpha$ signaling in embryonic ARC kisspeptin neurons, we observed that the vast majority of these cells express ER $\alpha$ during embryonic maturation (Fig. $8 C-E$ ).

\section{Discussion}

Kisspeptin neurons play an important role in the regulation of puberty onset and adult reproductive physiology in vertebrates, but little is known about their function and connectivity during embryonic and early postnatal development. Characterization of kisspeptin neural circuitry has been difficult due to their scattered distribution in the ARC and AVPe. Using complementary binary genetic strategies, we have started to characterize the development and connectivity of ARC kisspeptin neurons in the developing female mouse brain. Our genetic analyses show that ARC kisspeptin neurons are born between E12.5 and E13.5 in the female mouse brain, consistent with previous studies showing the presence of Kiss1 mRNA at E13.5 (Fiorini and Jasoni, 2010; Knoll et al., 2013). GPR54 expression is also first observed at E13.5, consistent with earlier reports demonstrating the presence of GPR54 mRNA at this stage (Constantin et al., 2009a; Fiorini and Jasoni, 2010; Knoll et al., 2013). At E16.5, 50\% of the adult ARC kisspeptin neuron population (Mayer et al., 2010) is already in place. Previous genetic analyses in mice have shown that embryonic gonadotropinreleasing hormone signaling is necessary for maturation of the reproductive axis (Wen et al., 2010). It is therefore tempting to speculate that fetal ARC kisspeptin neurons might act on fetal $\mathrm{GnRH}$ neurons and influence their activity, possibly via kisspeptin/GPR54 signaling. ARC kisspeptin neurons might indeed regulate embryonic GnRH secretion by stimulating GPR54, which would explain why GPR54 KO mice have significantly lower serum gonadotropin (luteinzing hormone and follicle-stimulating 
A

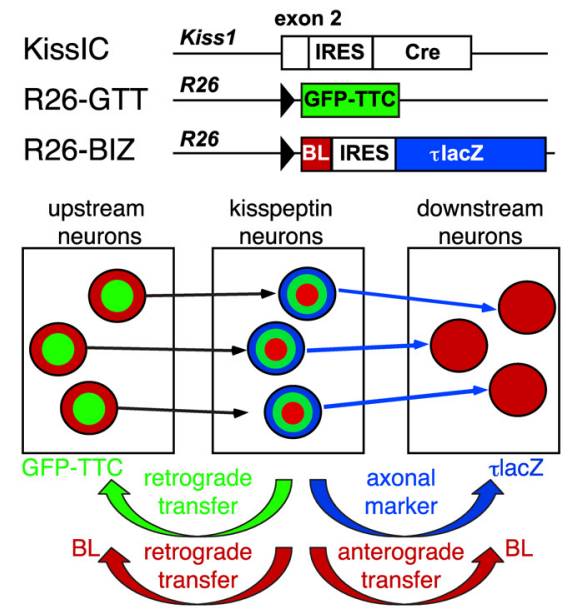

B
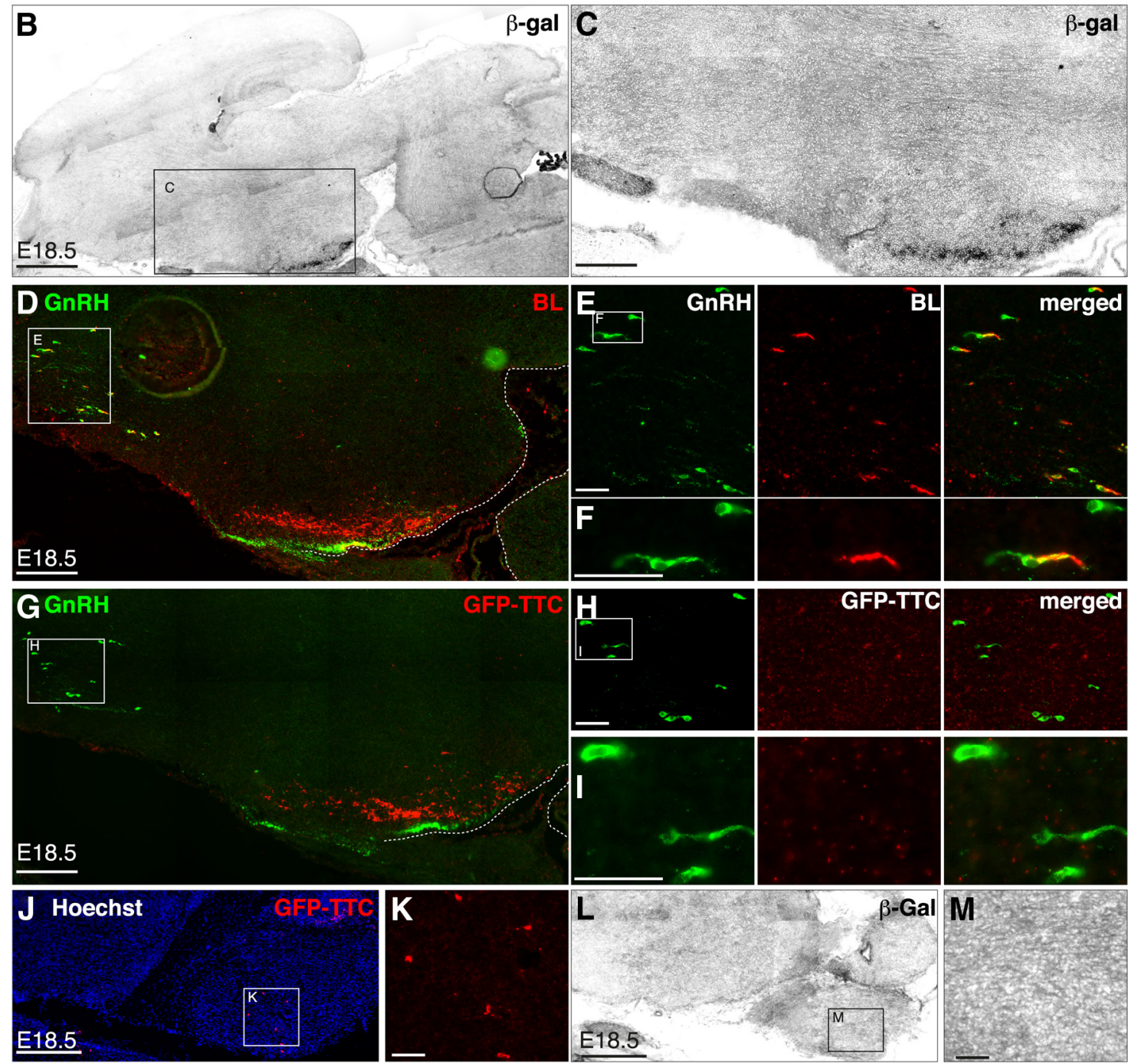

Figure 6. GnRH neurons are downstream of kisspeptin neurons. A, While BL is transferred to presynaptic and postsynaptic neurons in KissIC/R26-BIZ/R26-GTT mice, GFP-TTC transfer is restricted to presynaptic neurons. $B, C$, Histochemical analysis of $\beta$-galactosidase ( $\beta$-gal) activity in a sagittal section through the whole head of a female KissIC/R26-BIZ/R26-GTT triple-heterozygous mouse at E18.5. Note that $\beta$-gal activity is restricted to the ARC. $\boldsymbol{D}-\boldsymbol{F}$, Immunofluorescence for BL (red) and GnRH (green) on the section adjacent to the one shown in $\boldsymbol{B}$. Note that some, but not all, GnRH neurons contain BL. G-I, Immunofluorescence for GFP-TTC (red) and GnRH (green) on the section adjacent to the one shown in $\boldsymbol{B}$. Note that none of the GnRH neurons contain GFP-TTC. J, $\boldsymbol{K}$, Immunofluorescence for GFP-TTC (red) on a section prepared from a KissIC/R26-BIZ/R26-GTT mouse. GFP-TTC is found in cells outside of the preoptic area. $L, M$, Lack of $\beta$-gal activity in section adjacent to the one shown in $\boldsymbol{J}$ and $\boldsymbol{K}$ suggests transsynaptic transfer of the GFP-TTC tracer. Nuclei were stained with Hoechst 33258 dye (blue). Scale bars: $\boldsymbol{B}-\boldsymbol{D}, \boldsymbol{G}, \boldsymbol{J}, \boldsymbol{L}, 200 \mu \mathrm{m} ; \boldsymbol{E}, \boldsymbol{F}, \boldsymbol{H}, \boldsymbol{I}, \boldsymbol{K}, \boldsymbol{M}$, $50 \mu \mathrm{m}$. 

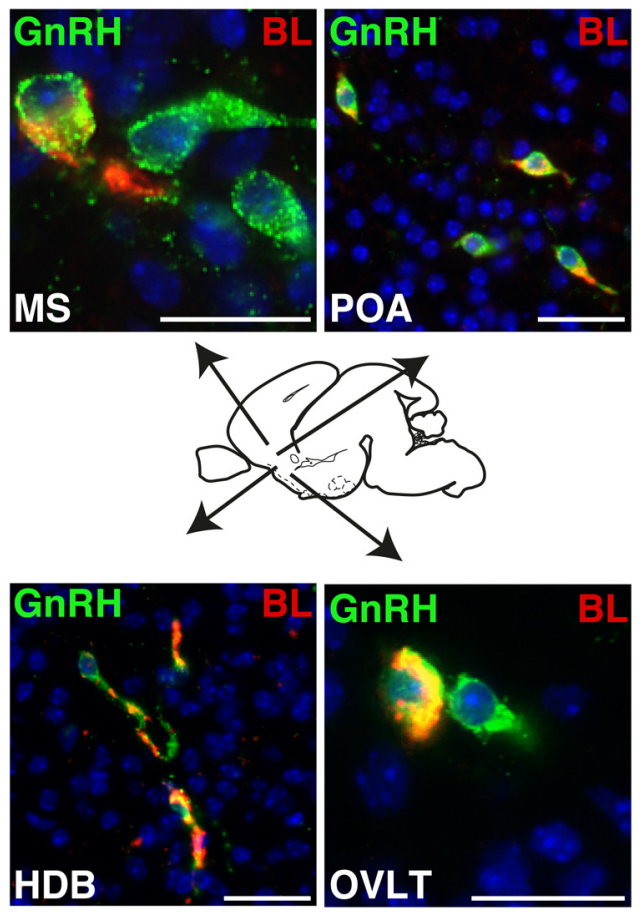

Figure 7. Connectivity and communication between ARC kisspeptin and GnRH neurons in utero is independent of their spatial position. Immunofluorescence for BL (red) and GnRH (green) is shown on a sagittal section through the head of a female KissIC/R26-BIZ mouse at $\mathrm{E} 18.5 . \mathrm{BL}^{+} / \mathrm{GnRH}^{+}$neurons are present in the medial septum (MS), the POA, the horizontal diagonal band of Broca (HDB), and the organum vasculosum of lamina terminalis (OVLT). Note that each area also contains GnRH neurons that do not communicate with kisspeptin neurons $\left(\mathrm{BL}^{-} / \mathrm{GnRH}^{+}\right)$. Scale bars, $50 \mu \mathrm{m}$.

hormone) levels compared with wild-type mice at P1 (Poling and Kauffman, 2012). Reduced serum gonadotropin levels are apparently due to lack of $\mathrm{GnRH}$ secretion, as serum gonadotropins are also significantly lower in $h p g$ mice lacking a functional $G n R H$ gene (Poling and Kauffman, 2012). Furthermore, earlier reports have demonstrated that GnRH neurons in nasal explants can respond to kisspeptin application in a dose-dependent manner similar to responses of $\mathrm{GnRH}$ in acute adult brain slice preparations (Constantin et al., 2009a,b).

Importantly, GPR54 expression is exclusively restricted to GnRH neurons during embryonic and early postnatal development. This is in contrast to adult GPR54 expression, which is found in many additional areas of the brain (Herbison et al., 2010; Mayer and Boehm, 2011), suggesting that the potential functional role of kisspeptin during early development is indeed-unlike in adult animals—restricted to GnRH neurons.

The neural circuitry of kisspeptin neurons has been difficult to analyze due to their scattered distribution within the ARC and AVPe (Yeo and Herbison, 2011). We developed two complementary mouse strains allowing Cre-dependent genetic transneuronal tracing to investigate the connectivity of kisspeptin neurons in the embryonic female mouse brain. One major limitation of other available tracing techniques is that most tracers must be stereotactically injected into the brain, which is technically challenging, especially in developing mouse brains in utero. Our strategy to express two complementary transsynaptic tracers and a stationary marker labeling the producing cell as transgenes from two knock-in alleles overcomes this limitation. This not only allowed us to visualize the connectivity between embryonic ARC kisspeptin neurons and GnRH neurons but also enabled us to compare the maturation of this connectivity at different time points (E16.5-P2). In contrast, comparative analyses of neural circuits over extended periods of time using neurotrophic viruses is usually not possible due to their cytotoxicity (Norgren and Lehman, 1998; Callaway, 2008). Therefore, the novel R26-BIZ and R26-GTT mouse strains should be useful to study neural circuits in addition to those underlying reproductive maturation. We chose to express the tracers under control of the constitutive and ubiquitous $R 26$ promoter rather than of the heavily regulated Kiss 1 promoter. This is an important point because it uncouples synaptic activity analysis from the upregulation or downregulation of one neuropeptide expressed by these cells. Therefore, transsynaptic BL and GTT transfer in KissIC/R26-BIZ/R26-GTT mice reflects synaptic communication between two neuronal populations independent of steroid hormone levels or other factors known to modulate kisspeptin expression (Clarkson et al., 2009a; Clarkson, 2013; Poling and Kauffman, 2013).

Cre-dependent genetic transneuronal tracing from kisspeptin neurons revealed intense synaptic connectivity between ARC kisspeptin and GnRH neurons early in development. Remarkably, these neural circuits are established and operative before birth. Not all perinatal GnRH neurons are BL positive, suggesting functional subpopulations of $\mathrm{GnRH}$ neurons at this developmental time point. This is consistent with studies showing that only subsets of GnRH neurons in adult mice respond to kisspeptin (Dumalska et al., 2008; Constantin et al., 2009a,b). Differential onset of kisspeptin expression in the ARC and AVPe allowed us to selectively study neural connectivity of the ARC kisspeptin neuron population using this approach. While kisspeptin expression in the AVPe begins between P10 and P15 (Semaan et al., 2010; Losa et al., 2011), the majority of this second major population of kisspeptin neurons in the female rodent brain start to express kisspeptin mainly during puberty (Clarkson and Herbison, 2006; Oakley et al., 2009; Mayer et al., 2010; Knoll et al., 2013). Consistent with this, $\tau$ GFP reporter expression in KissIC/ eR26- $\tau$ GFP brains remained restricted to the ARC at all embryonic ages analyzed (E12.5, E13.5, E14.5, and E16.5). Furthermore, $\beta$-galactosidase activity was only found in the ARC in female KissIC/R26-BIZ brains at E18.5. Analysis of older KissIC/ R26-BIZ/R26-GTT females should also provide additional information about the neural circuitry of AVPe kisspeptin neurons. While we focused on the analysis of the female brain in this study, it will be interesting to compare kisspeptin neural circuits in male and female mice at different time points. Furthermore, transneuronal transfer of BL and GTT in KissIC/R26-BIZ/R26-GTT females is not restricted to $\mathrm{GnRH}$ neurons at later embryonic and perinatal stages (Fig. $6 \mathrm{~J}, \mathrm{~K}$ ), and comparative analysis of $\mathrm{BL}$ and/or GTT-labeled cells throughout the brain of these animals should provide detailed information about kisspeptin neural circuitry independent of GnRH neurons.

Our data provide substantial new insight into functional organization of the circuitry underlying reproductive maturation in the female brain. Communication between kisspeptin and $\mathrm{GnRH}$ neurons is established with remarkable specificity arguing against an overabundance of connections needed for the formation of reproductive circuitry in the developing brain (Low and Cheng, 2006). We observed similar numbers of $\mathrm{BL}^{+} / \mathrm{GnRH}^{+}$ and $\mathrm{BL}^{-} / \mathrm{GnRH}^{+}$neurons, not only in different regions of the brain but also in different animals (Fig. $4 G$ ), raising the possibility that connectivity between kisspeptin and GnRH neurons is stereotyped.

We have recently shown that an $\mathrm{ER} \alpha$-dependent mechanism-acting like a "brake" — is operating in arcuate kisspeptin- 
producing neurons during pubertal development of female mice to gate $\mathrm{GnRH}$ release. Conditional inactivation of the Esrl gene in kisspeptin neurons results in a dramatic advancement of puberty onset in female mice (Mayer et al., 2010). These data suggest that an $\mathrm{ER} \alpha$ dependent mechanism is acting in ARC kisspeptin neurons during female reproductive maturation. Consistent with this, the birthplace of ARC kisspeptin neurons in the developing hypothalamus is delineated by estrogen-sensitive cells, and most ARC kisspeptin neurons already express $\mathrm{ER} \alpha$ in utero. While the role of estrogens during female reproductive maturation remains controversial (Bakker and Baum, 2008), it seems interesting to note that the first appearance of $\operatorname{ER} \alpha$ immunoreactivity in the fetal female mouse brain coincides - both temporally and spatiallywith the first activity of the Kiss1 promoter. These data may suggest a role for ER $\alpha$ signaling in fetal ARC kisspeptin neurons. Where could the fetal estrogen potentially come from? The fetal mouse ovaries are an unlikely source, as they do not express some of the enzymes necessary for estrogen production early in development (Greco and Payne, 1994). One alternative source might be local estrogen production in the brain. Future studies will be directed at determining the source of estrogen in the fetal female mouse brain and at analyzing its effect on the fetal ARC kisspeptin neuron population.

Together, we have started to delineate the neural circuits controlling the timing of reproductive maturation using conditional genetic transsynaptic tracing in female mouse embryos. Our genetic analyses show that kisspeptin is first expressed at E13.5 in the arcuate nucleus of the hypothalamus. We demonstrate that arcuate kisspeptin neurons already communicate with a specific subset of GnRH neurons in utero. We also show that arcuate kisspeptin neurons are upstream of GnRH neurons and that GnRH neuron connectivity to arcuate kisspeptin neurons does not depend on their spatial position in the brain. Furthermore, our data indicate that the neural circuits between ARC kisspeptin and GnRH neurons are fully established and operative before birth. Finally, our data show that most GnRH neurons express the kisspeptin receptor GPR54 upon circuit formation, raising the possibility that the signaling system implicated in gatekeeping puberty becomes operative in the embryo.

\section{References}

Abreu AP, Dauber A, Macedo DB, Noel SD, Brito VN, Gill JC, Cukier P, Thompson IR, Navarro VM, Gagliardi PC, Rodrigues T, Kochi C, Longui CA, Beckers D, de Zegher F, Montenegro LR, Mendonca BB, Carroll RS,
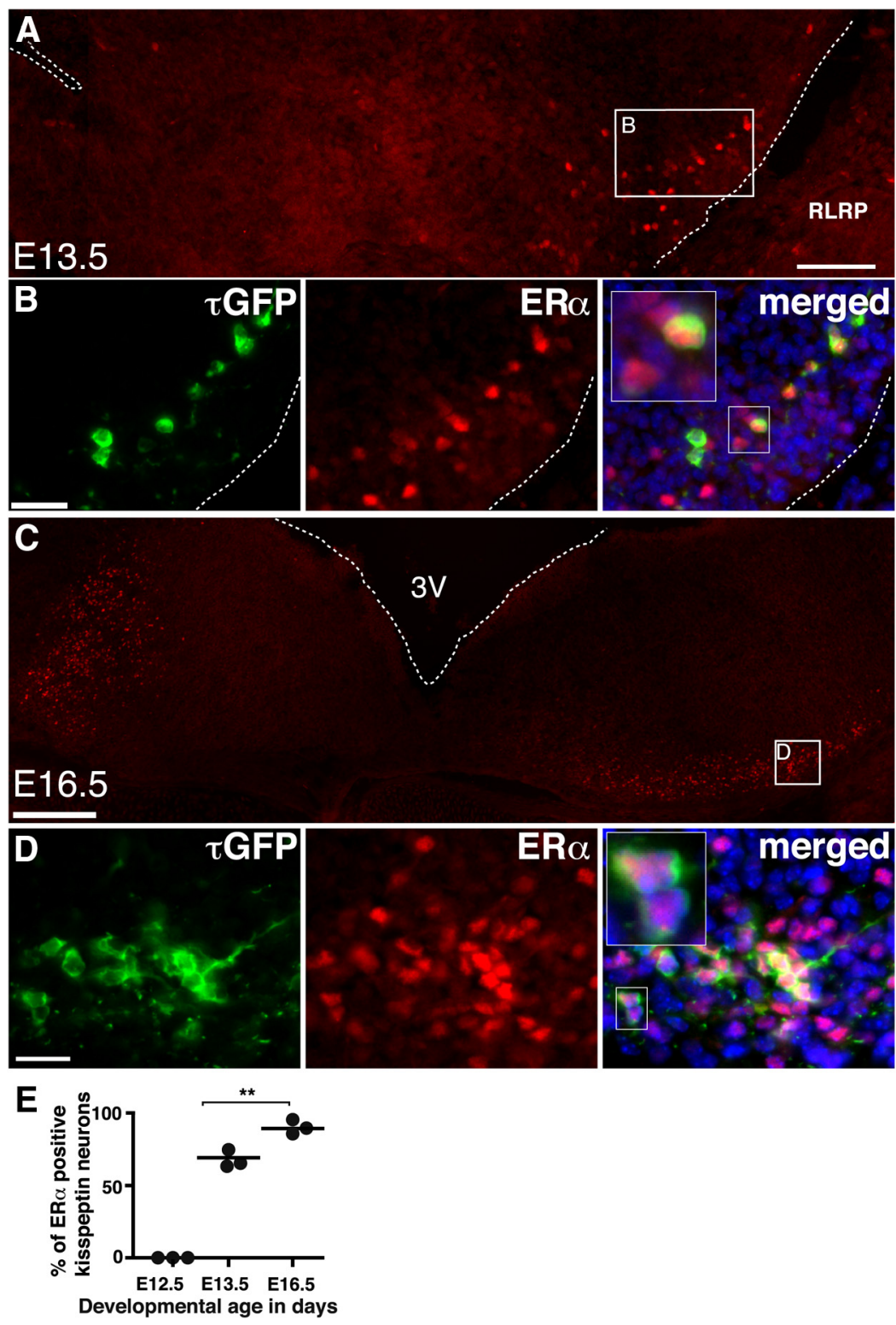

Figure 8. Fetal ARC kisspeptin neurons express ER $\alpha$. A-D, Immunofluorescence for $E R \alpha$ (red) and $\tau \mathrm{GFP}$ (green) of sagittal sections through the head of female KissIC/eR26- TGFP embryos at E13.5 $(\boldsymbol{A}, \boldsymbol{B})$ and E16.5 $(\boldsymbol{C}, \boldsymbol{D})$. Note that ER $\alpha$ immunoreactivity is restricted to the mediobasal hypothalamus at E13.5. Most ARC kisspeptin neurons express ER $\alpha$ at E16.5. Merged images also display nuclear counterstaining (Hoechst 33258 stain, blue). Please note that the ER $\alpha$ immunoreactivity in kisspeptin neurons seems to be localized to the nucleus (inset). $\boldsymbol{E}$, Quantification of kisspeptin/ER $\alpha$ neurons during embryonic maturation. No ER $\alpha$ expression was found at E12.5; at E13.5, nearly $70 \%$ of kisspeptin neurons were ER $\alpha$ positive $\left(43 \pm 7 \mathrm{ER} \alpha^{+} / \tau \mathrm{GFP}{ }^{+}\right.$of $61 \pm 10$ $\tau_{\mathrm{GFP}}{ }^{+}, n=3$ mice), increasing to $90 \%$ at E16.5 $\left(340 \pm 10 \mathrm{ER} \alpha^{+} / \tau \mathrm{GFP}^{+}\right.$of $378 \pm 6 \tau \mathrm{GFP}^{+} ; n=3$ mice, $\left.{ }^{* *} p<0.01\right) .3 \mathrm{~V}$, Third ventricle; RLRP, residual lumen of Rathke's pouch. Scale bars: $\boldsymbol{A}, \boldsymbol{C}, 200 \mu \mathrm{m} ; \boldsymbol{B}, \boldsymbol{D}, 50 \mu \mathrm{m}$.

Hirschhorn JN, Latronico AC, et al (2013) Central precocious puberty caused by mutations in the imprinted gene MKRN3. N Engl J Med 368: 2467-2475. CrossRef Medline

Agulnik AI, Bishop CE, Lerner JL, Agulnik SI, Solovyev VV (1997) Analysis of mutation rates in the SMCY/SMCX genes shows that mammalian evolution is male driven. Mamm Genome 8:134-138. CrossRef Medline

Aubert ML, Begeot M, Winiger BP, Morel G, Sizonenko PC, Dubois PM (1985) Ontogeny of hypothalamic luteinizing hormone-releasing hormone $(\mathrm{GnRH})$ and pituitary $\mathrm{GnRH}$ receptors in fetal and neonatal rats. Endocrinology 116:1565-1576. CrossRef Medline

Bakker J, Baum MJ (2008) Role for estradiol in female-typical brain and behavioral sexual differentiation. Front Neuroendocrinol 29:1-16. CrossRef Medline

Boehm U, Zou Z, Buck LB (2005) Feedback loops link odor and pheromone signaling with reproduction. Cell 123:683-695. CrossRef Medline

Brock O, Bakker J (2013) The two kisspeptin neuronal populations are dif- 
ferentially organized and activated by estradiol in mice. Endocrinology 154:2739-2749. CrossRef Medline

Bronson FH (1981) The regulation of luteinizing hormone secretion by estrogen: relationships among negative feedback, surge potential, and male stimulation in juvenile, peripubertal, and adult female mice. Endocrinology 108:506-516. CrossRef Medline

Buch T, Heppner FL, Tertilt C, Heinen TJ, Kremer M, Wunderlich FT, Jung S, Waisman A (2005) A Cre-inducible diphtheria toxin receptor mediates cell lineage ablation after toxin administration. Nat Methods 2:419-426. CrossRef Medline

Callaway EM (2008) Transneuronal circuit tracing with neurotropic viruses. Curr Opin Neurobiol 18:617-623. CrossRef Medline

Cao J, Patisaul HB (2011) Sexually dimorphic expression of hypothalamic estrogen receptors alpha and beta and Kiss1 in neonatal male and female rats. J Comp Neurol 519:2954-2977. CrossRef Medline

Castellano JM, Gaytan M, Roa J, Vigo E, Navarro VM, Bellido C, Dieguez C, Aguilar E, Sánchez-Criado JE, Pellicer A, Pinilla L, Gaytan F, TenaSempere M (2006) Expression of KiSS-1 in rat ovary: putative local regulator of ovulation? Endocrinology 147:4852-4862. CrossRef Medline

Clarkson J (2013) Effects of estradiol on kisspeptin neurons during puberty. Front Neuroendocrinol 34:120-131. CrossRef Medline

Clarkson J, Herbison AE (2006) Postnatal development of kisspeptin neurons in mouse hypothalamus; sexual dimorphism and projections to gonadotropin-releasing hormone neurons. Endocrinology 147:58175825. CrossRef Medline

Clarkson J, Boon WC, Simpson ER, Herbison AE (2009a) Postnatal development of an estradiol-kisspeptin positive feedback mechanism implicated in puberty onset. Endocrinology 150:3214-3220. CrossRef Medline

Clarkson J, d'Anglemont de Tassigny X, Colledge WH, Caraty A, Herbison AE (2009b) Distribution of kisspeptin neurones in the adult female mouse brain. J Neuroendocrinol 21:673-682. CrossRef Medline

Clarkson J, Han SK, Liu X, Lee K, Herbison AE (2010) Neurobiological mechanisms underlying kisspeptin activation of gonadotropin-releasing hormone (GnRH) neurons at puberty. Mol Cell Endocrinol 324:45-50. CrossRef Medline

Constantin S, Caligioni CS, Stojilkovic S, Wray S (2009a) Kisspeptin-10 facilitates a plasma membrane-driven calcium oscillator in gonadotropinreleasing hormone-1 neurons. Endocrinology 150:1400-1412. CrossRef Medline

Constantin S, Caraty A, Wray S, Duittoz AH (2009b) Development of gonadotropin-releasing hormone-1 secretion in mouse nasal explants. Endocrinology 150:3221-3227. CrossRef Medline

d'Anglemont de Tassigny X, Fagg LA, Dixon JP, Day K, Leitch HG, Hendrick AG, Zahn D, Franceschini I, Caraty A, Carlton MB, Aparicio SA, Colledge WH (2007) Hypogonadotropic hypogonadism in mice lacking a functional Kiss1 gene. Proc Natl Acad Sci U S A 104:10714-10719. CrossRef Medline

de Roux N, Genin E, Carel JC, Matsuda F, Chaussain JL, Milgrom E (2003) Hypogonadotropic hypogonadism due to loss of function of the KiSS1derived peptide receptor GPR54. Proc Natl Acad Sci U S A 100:1097210976. CrossRef Medline

Desroziers E, Droguerre M, Bentsen AH, Robert V, Mikkelsen JD, Caraty A, Tillet Y, Duittoz A, Franceschini I (2012) Embryonic development of kisspeptin neurones in rat. J Neuroendocrinol 24:1284-1295. CrossRef Medline

Dumalska I, Wu M, Morozova E, Liu R, van den Pol A, Alreja M (2008) Excitatory effects of the puberty-initiating peptide kisspeptin and group I metabotropic glutamate receptor agonists differentiate two distinct subpopulations of gonadotropin-releasing hormone neurons. J Neurosci 28: 8003-8013. CrossRef Medline

Fiorini Z, Jasoni CL (2010) A novel developmental role for kisspeptin in the growth of gonadotrophin-releasing hormone neurites to the median eminence in the mouse. J Neuroendocrinol 22:1113-1125. CrossRef Medline

Greco TL, Payne AH (1994) Ontogeny of expression of the genes for steroidogenic enzymes $\mathrm{P} 450$ side-chain cleavage, 3 beta-hydroxysteroid dehydrogenase, P450 17 alpha-hydroxylase/C17-20 lyase, and P450 aromatase in fetal mouse gonads. Endocrinology 135:262-268. CrossRef Medline

Han SK, Gottsch ML, Lee KJ, Popa SM, Smith JT, Jakawich SK, Clifton DK, Steiner RA, Herbison AE (2005) Activation of gonadotropin-releasing hormone neurons by kisspeptin as a neuroendocrine switch for the onset of puberty. J Neurosci 25:11349-11356. CrossRef Medline
Herbison AE, de Tassigny Xd, Doran J, Colledge WH (2010) Distribution and postnatal development of Gpr54 gene expression in mouse brain and gonadotropin-releasing hormone neurons. Endocrinology 151:312-321. CrossRef Medline

Horowitz LF, Montmayeur JP, Echelard Y, Buck LB (1999) A genetic approach to trace neural circuits. Proc Natl Acad Sci U S A 96:3194-3199. CrossRef Medline

Irwig MS, Fraley GS, Smith JT, Acohido BV, Popa SM, Cunningham MJ, Gottsch ML, Clifton DK, Steiner RA (2004) Kisspeptin activation of gonadotropin releasing hormone neurons and regulation of KiSS-1 mRNA in the male rat. Neuroendocrinology 80:264-272. CrossRef Medline

Kaufmann MH (2001) The atlas of mouse development, Ed 2. Amsterdam: Elsevier Academic.

Knoll JG, Clay CM, Bouma GJ, Henion TR, Schwarting GA, Millar RP, Tobet SA (2013) Developmental profile and sexually dimorphic expression of kiss 1 and kiss1r in the fetal mouse brain. Front Endocrinol (Lausanne) 4:140. CrossRef Medline

Lo L, Anderson DJ (2011) A Cre-dependent, anterograde transsynaptic viral tracer for mapping output pathways of genetically marked neurons. Neuron 72:938-950. CrossRef Medline

Losa SM, Todd KL, Sullivan AW, Cao J, Mickens JA, Patisaul HB (2011) Neonatal exposure to genistein adversely impacts the ontogeny of hypothalamic kisspeptin signaling pathways and ovarian development in the peripubertal female rat. Reprod Toxicol 31:280-289. CrossRef Medline

Low LK, Cheng HJ (2006) Axon pruning: an essential step underlying the developmental plasticity of neuronal connections. Philos Trans R Soc Lond B Biol Sci 361:1531-1544. CrossRef Medline

Maskos U, Kissa K, St Cloment C, Brûlet P (2002) Retrograde trans-synaptic transfer of green fluorescent protein allows the genetic mapping of neuronal circuits in transgenic mice. Proc Natl Acad Sci U S A 99:1012010125. CrossRef Medline

Matsui H, Takatsu Y, Kumano S, Matsumoto H, Ohtaki T (2004) Peripheral administration of metastin induces marked gonadotropin release and ovulation in the rat. Biochem Biophys Res Commun 320:383-388. CrossRef Medline

Mayer C, Boehm U (2011) Female reproductive maturation in the absence of kisspeptin/GPR54 signaling. Nat Neurosci 14:704-710. CrossRef Medline

Mayer C, Acosta-Martinez M, Dubois SL, Wolfe A, Radovick S, Boehm U, Levine JE (2010) Timing and completion of puberty in female mice depend on estrogen receptor alpha-signaling in kisspeptin neurons. Proc Natl Acad Sci U S A 107:22693-22698. CrossRef Medline

Nakashiba T, Cushman JD, Pelkey KA, Renaudineau S, Buhl DL, McHugh TJ, Rodriguez Barrera V, Chittajallu R, Iwamoto KS, McBain CJ, Fanselow MS, Tonegawa S (2012) Young dentate granule cells mediate pattern separation, whereas old granule cells facilitate pattern completion. Cell 149:188-201. CrossRef Medline

Navarro VM, Fernández-Fernández R, Castellano JM, Roa J, Mayen A, Barreiro ML, Gaytan F, Aguilar E, Pinilla L, Dieguez C, Tena-Sempere M (2004) Advanced vaginal opening and precocious activation of the reproductive axis by KiSS-1 peptide, the endogenous ligand of GPR54. J Physiol 561:379-386. CrossRef Medline

Norgren RB Jr, Lehman MN (1998) Herpes simplex virus as a transneuronal tracer. Neurosci Biobehav Rev 22:695-708. CrossRef Medline

Oakley AE, Clifton DK, Steiner RA (2009) Kisspeptin signaling in the brain. Endocr Rev 30:713-743. CrossRef Medline

Pineda R, Garcia-Galiano D, Roseweir A, Romero M, Sanchez-Garrido MA, Ruiz-Pino F, Morgan K, Pinilla L, Millar RP, Tena-Sempere M (2010) Critical roles of kisspeptins in female puberty and preovulatory gonadotropin surges as revealed by a novel antagonist. Endocrinology 151:722730. CrossRef Medline

Poling MC, Kauffman AS (2012) Sexually dimorphic testosterone secretion in prenatal and neonatal mice is independent of kisspeptin-Kiss1 $\mathrm{r}$ and GnRH signaling. Endocrinology 153:782-793. CrossRef Medline

Poling MC, Kauffman AS (2013) Organizational and activational effects of sex steroids on kisspeptin neuron development. Front Neuroendocrinol 34:3-17. CrossRef Medline

Rodriguez I, Feinstein P, Mombaerts P (1999) Variable patterns of axonal projections of sensory neurons in the mouse vomeronasal system. Cell 97:199-208. CrossRef Medline

Schambra U (2008) Prenatal mouse brain atlas. New York: Springer. 
Schwanzel-Fukuda M, Pfaff DW (1989) Origin of luteinizing hormonereleasing hormone neurons. Nature 338:161-164. CrossRef Medline

Semaan SJ, Murray EK, Poling MC, Dhamija S, Forger NG, Kauffman AS (2010) BAX-dependent and BAX-independent regulation of Kiss1 neuron development in mice. Endocrinology 151:5807-5817. CrossRef Medline

Seminara SB, Crowley WF Jr (2008) Kisspeptin and GPR54: discovery of a novel pathway in reproduction. J Neuroendocrinol 20:727-731. CrossRef Medline

Seminara SB, Messager S, Chatzidaki EE, Thresher RR, Acierno JS Jr, Shagoury JK, Bo-Abbas Y, Kuohung W, Schwinof KM, Hendrick AG, Zahn D, Dixon J, Kaiser UB, Slaugenhaupt SA, Gusella JF, O’Rahilly S, Carlton MB, Crowley WF Jr, Aparicio SA, Colledge WH (2003) The GPR54 gene as a regulator of puberty. $\mathrm{N}$ Engl J Med 349:1614-1627. CrossRef Medline

Sisk CL, Foster DL (2004) The neural basis of puberty and adolescence. Nat Neurosci 7:1040-1047. CrossRef Medline

Smith JT, Popa SM, Clifton DK, Hoffman GE, Steiner RA (2006) Kiss1 neurons in the forebrain as central processors for generating the preovulatory luteinizing hormone surge. J Neurosci 26:6687-6694. CrossRef Medline

Styne DM, Grumbach MM (2008) Puberty: ontogeny, neuroendocrinology, physiology, and disorders. In: Williams textbook of endocrinology, Ed 10 (Larsen PR, Kronenberg HM, Melmed S, Larsen PR, eds), pp 9691166. Philadelphia: Saunders.

Tabuchi K, Sawamoto K, Suzuki E, Ozaki K, Sone M, Hama C, TanifujiMorimoto T, Yuasa Y, Yoshihara Y, Nose A, Okano H (2000) GAL4/
UAS-WGA system as a powerful tool for tracing Drosophila transsynaptic neural pathways. J Neurosci Res 59:94-99. CrossRef Medline

Teles MG, Bianco SD, Brito VN, Trarbach EB, Kuohung W, Xu S, Seminara SB, Mendonca BB, Kaiser UB, Latronico AC (2008) A GPR54-activating mutation in a patient with central precocious puberty. N Engl J Med 358:709-715. CrossRef Medline

Terasawa E, Fernandez DL (2001) Neurobiological mechanisms of the onset of puberty in primates. Endocr Rev 22:111-151. CrossRef Medline

Topaloglu AK, Tello JA, Kotan LD, Ozbek MN, Yilmaz MB, Erdogan S, Gurbuz F, Temiz F, Millar RP, Yuksel B (2012) Inactivating KISS1 mutation and hypogonadotropic hypogonadism. N Engl J Med 366:629-635. CrossRef Medline

Wen S, Ai W, Alim Z, Boehm U (2010) Embryonic gonadotropin-releasing hormone signaling is necessary for maturation of the male reproductive axis. Proc Natl Acad Sci U S A 107:16372-16377. CrossRef Medline

Wen S, Götze IN, Mai O, Schauer C, Leinders-Zufall T, Boehm U (2011) Genetic identification of GnRH receptor neurons: a new model for studying neural circuits underlying reproductive physiology in the mouse brain. Endocrinology 152:1515-1526. CrossRef Medline

Wray S, Grant P, Gainer H (1989) Evidence that cells expressing luteinizing hormone-releasing hormone mRNA in the mouse are derived from progenitor cells in the olfactory placode. Proc Natl Acad Sci U S A 86:81328136. CrossRef Medline

Yeo SH, Herbison AE (2011) Projections of arcuate nucleus and rostral periventricular kisspeptin neurons in the adult female mouse brain. Endocrinology 152:2387-2399. CrossRef Medline 